\title{
Transient Hemichorea/Hemiballismus Associated with New Onset Hyperglycemia
}

\author{
G. Ifergane, R. Masalha, Y.O. Herishanu
}

\begin{abstract}
Objective: To describe three patients suffering from transient hemichorea/hemiballismus associated with hyperglycemia, review previous reports and propose a possible pathophysiological explanation for this phenomenon. Results: Our original cases and previously reported ones reveal a uniform syndrome: mostly female patients (F/M ratio of 11/2), 50-80 years old, usually with no previous history of diabetes mellitus (9/13), develop choreic or ballistic movements on one side of the body over a period of hours. Serum glucose levels are elevated. In most of the patients, a lowering of the blood sugar level reverses the movement disorder within 24-48 hours. Conclusions: We believe that the combination of a recent or old striatal lesion (causing increased inhibition of the subthalamic nucleus) and hyperglycemia (causing decreased GABAergic inhibition of the thalamus) may be responsible for the appearance of this unilateral hyperkinetic movement disorder. Undiagnosed diabetes mellitus should always be suspected in patients who develop hemiballistic or hemichoreic movements. When hyperglycemia is detected and corrected, the movement disorder usually resolves within two days and may not require symptomatic therapy with dopamine receptor antagonists.
\end{abstract}

RÉSUMÉ: Hémichorée transitoire/hémiballisme associé à une hyperglycémie d'apparition récente. Objectif: Le but de cet article est de décrire trois patients ayant présenté une hémichorée/hémiballisme transitoire en association à une hyperglycémie, de revoir les cas rapportés dans la littérature et de proposer une explication physiopathologique de ce phénomène. Résultats: Nos cas et ceux qui ont été rapportés dans la littérature présentaient un syndrome uniforme: une majorité de femmes (proportion $\mathrm{F} / \mathrm{H}$ de 11/2), dont l'âge variait de 50 à 80 ans, habituellement sans histoire antérieure de diabète (9/13), qui développent des mouvements choréiques ou ballistiques d'un côté du corps en quelques heures. La glycémie est élevée. Chez la plupart des patients, une baisse de la glycémie fait régresser le désordre du mouvement en 24 à 48 heures. Conclusions: Nous croyons que la combinaison d'une lésion striatale récente ou ancienne (causant une augmentation de l'inhibition du noyau sousthalamique) et d'une hyperglycémie (causant une diminution de l'inhibition GABAergique du thalamus) pourraient être responsables de l'apparition de ce désordre du mouvement hyperkinétique unilatéral. Un diabète non diagnostiqué devrait toujours être soupçonné chez les patients qui développent des mouvements hémiballiques ou hémichoréiques. Quand l'hyperglycémie est détectée et corrigée, le désordre du mouvement disparaît en deux jours et ne requiert habituellement pas de traitement symptomatique au moyen d'antagonistes des récepteurs dopaminergiques.

Can. J. Neurol. Sci. 2001; 28: 365-368

Hemiballismus/hemichorea constitute a neurological syndrome characterized by violent proximal involuntary movements on one side of the body, involving mainly the upper extremity. They are usually associated with small infarcts or hemorrhages in the vicinity of the subthalamic nucleus. Tumors, granulomas and surgical lesions were also reported as causative pathologies. Lesions in different sites of the striatum e.g. the subthalamic fasciculus and the head of the caudate nucleus ${ }^{1}$ were reported to cause hemiballismus as well.

In the last two decades, several patients ${ }^{2-10}$ suffering from hemichorea or hemiballismus, associated with hyperglycemia and diabetes, were reported. In this paper we describe three other cases, review the literature on the subject and propose a possible pathophysiological explanation for this phenomenon.

From the Department of Neurology, Soroka Medical Center, Faculty of Health Sciences, Ben Gurion University, Beer Sheva, Israel.

ReCeIved November 27, 2000. ACCEPTED IN FinAl FORM August 23, 2001 Reprint requests to: Gal Ifergane, Department of Neurology, Soroka Medical Center, PO Box 151, Beer Sheva, Israel 


\section{Case Reports}

Patient 1: A 71-year-old woman was admitted to the internal medicine department because of choreiform movements in her left limbs, which had developed gradually on the day of her admission. Her medical history was unremarkable and there was no family history of chorea. Besides the movement disorder, the neurological examination yielded normal findings. Laboratory tests showed a blood sugar level of 560 $\mathrm{mg} / \mathrm{dl}$. A CT scan of the brain was normal. The hemichorea resolved 24 hours after the correction of the hyperglycemia. No residual neurological deficit was found.

Patient 2: A 78-year-old woman, with no family history of chorea, presented with left hemichorea, which had started two days earlier. The patient was known to suffer from hypertension. Repeated blood sugar level evaluations in the previous years were normal. A brain CT scan was normal and laboratory tests revealed an elevated blood sugar level (490 $\mathrm{mg} / \mathrm{dl})$. Correction of the hyperglycemia resulted in disappearance of the movement disorder within 24 hours. The neurological examination was normal on discharge. On a three-year follow-up, no abnormal movements were noted and no signs of cerebrovascular disease were found.

Patient 3: An otherwise healthy 54-year-old woman was admitted to the neurology department because of right hemiballismus, which appeared a week prior to her admission. There was no family history of chorea. Blood sugar levels were $460 \mathrm{mg} / \mathrm{dl}$ on admission. A CT scan of the brain demonstrated a discrete hyperdense lesion in her left basal ganglia without mass effect or contrast enhancement. A high intensity lesion was observed on a T1-weighted MRI in the same area (Figure 1). Haloperidol $1 \mathrm{mg}$ was instituted in parallel with hypoglycemic therapy.

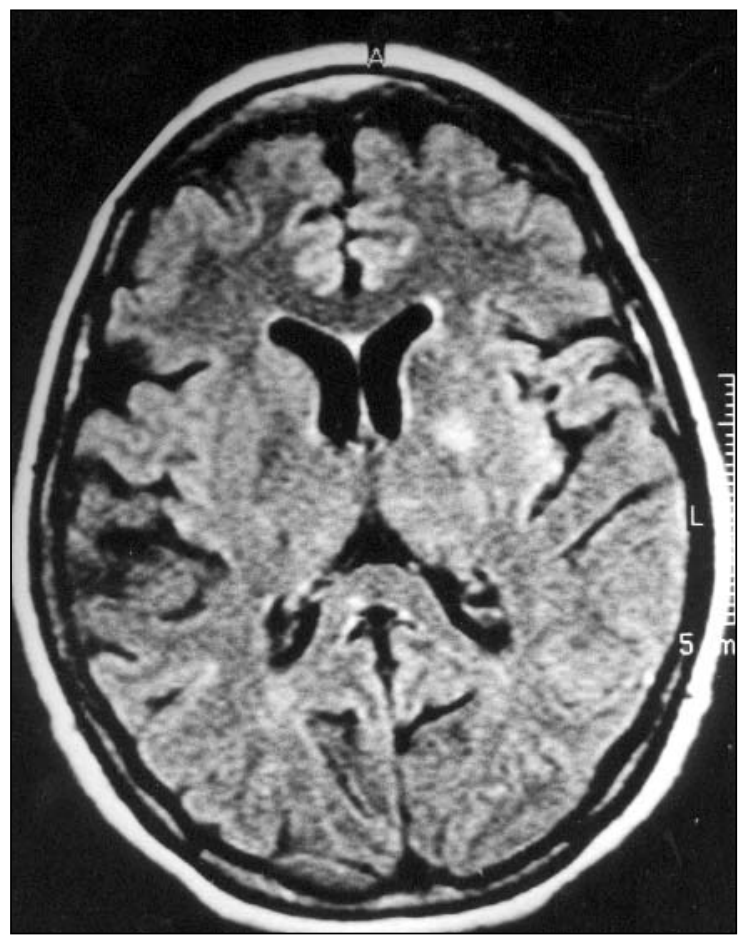

Figure 1: A T1-weighted MRI of patient 3 demonstrating a hyperintense lesion in the basal ganglia.

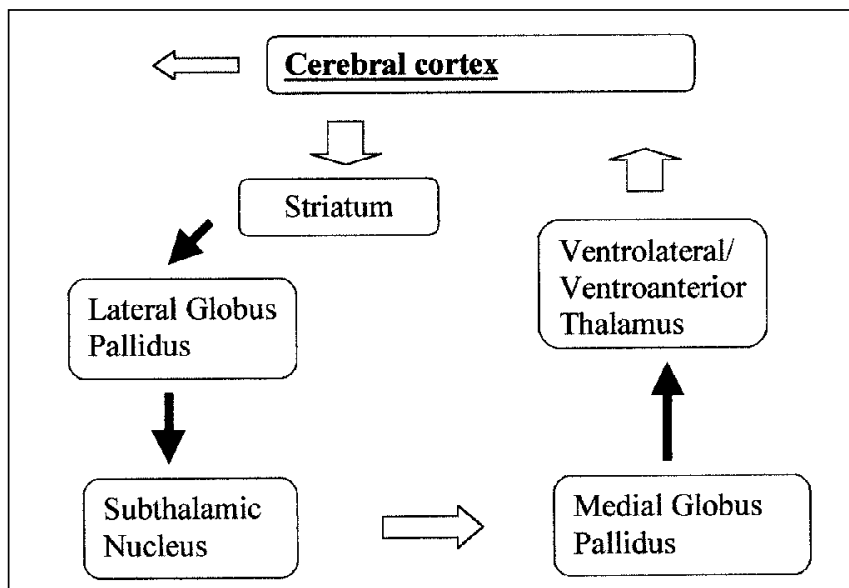

Figure 2a

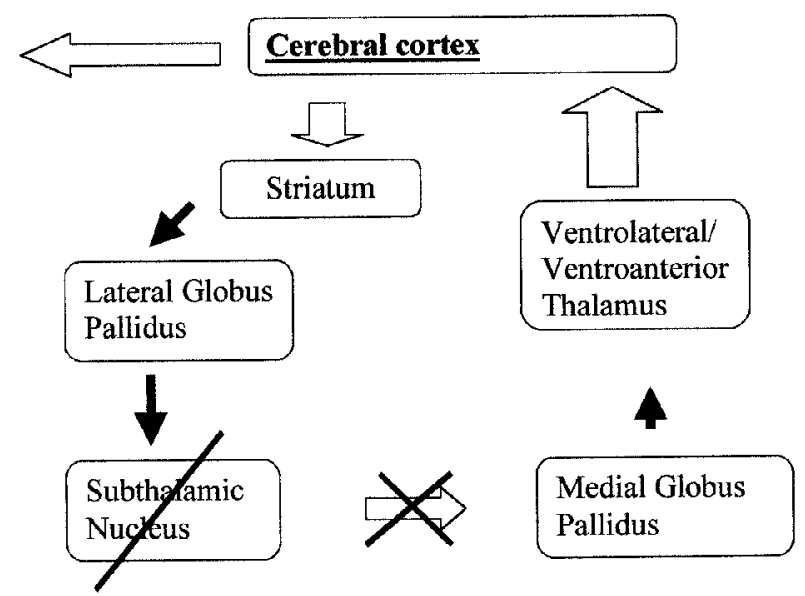

Figure 2b

Figure 2: The normal indirect pathway of the cortico - basal ganglia thalamic circuit is shown in Figure $2 a$. A lesion in the subthalamic nucleus (2b) disrupts the excitation of the medial part of the globus pallidus, thereby decreasing its inhibitory influence on the ventrolateral and ventroanterior thalamus. The resulting increase of excitation of the motor and supplementary cortex gives rise to hemichorea or hemiballismus.

Three days later, the blood sugar level was normal, the symptoms resolved and haloperidol was discontinued. The results of neurological examination were normal on discharge. Hemiballismus did not recur after cessation of haloperidol. On a two-year follow-up, the movement disorder was not observed and no strokes or transient ischemic attacks were documented.

\section{Discussion}

Unilateral proximal involuntary movements (hemichorea or hemiballismus) are frequently associated with subthalamic nucleus lesions. The subthalamic nucleus is a lens-shaped group of cells ventral to the thalamus. Its neurons utilize the excitatory neurotransmitter glutamate. They serve as the main excitatory input to the medial part of the globus pallidus, which inhibits (by 
Table: Reported cases of hyperglycemia-associated hemichorea

\begin{tabular}{|c|c|c|c|c|c|c|c|}
\hline & $\begin{array}{c}\text { No. of } \\
\text { patients }\end{array}$ & Sex & $\begin{array}{l}\text { Range of } \\
\text { ages }\end{array}$ & $\begin{array}{c}\text { Range of } \\
\text { blood glucose } \\
\text { levels* }\end{array}$ & Recovery time ${ }^{* *}$ & CT & MRI \\
\hline $\begin{array}{l}\text { Bedwell }^{12} \\
1960\end{array}$ & 1 & $\mathrm{~F}$ & 65 & 450 & $4 w$ & Not performed & Not performed \\
\hline $\begin{array}{l}\text { Rector }^{2} \\
1982\end{array}$ & 3 & $\begin{array}{l}\mathrm{F}-2 \\
\mathrm{M}-1\end{array}$ & $46-80$ & $456-1000$ & $18-24 \mathrm{~h}$ & Normal & Not performed \\
\hline $\begin{array}{l}\operatorname{Lin}^{4} \\
1994\end{array}$ & 3 & $\begin{array}{l}F-2 \\
M-1\end{array}$ & $74-78$ & $547-1102$ & $24-48 \mathrm{~h}$ & 2 - normal & $\begin{array}{l}\text { Not performed } \\
1-\text { old basal-ganglia infarct }\end{array}$ \\
\hline $\begin{array}{l}\text { Takamatsu }^{5} \\
1995\end{array}$ & 2 & $F-2$ & $67-68$ & $365-695$ & Not specified & $1-$ normal & $\begin{array}{l}1 \text { - hyperintense } \mathrm{T} 1 \text { putamen } \\
\text { lesion }\end{array}$ \\
\hline Our series & 3 & $F-3$ & $54-78$ & $460-560$ & $24-48 \mathrm{~h}$ & $\begin{array}{l}2 \text { - normal } \\
1 \text { - hyperdense basal } \\
\quad \text { ganglia lesion }\end{array}$ & $\begin{array}{l}1 \text { - hyperintense } \mathrm{T} 1 \text { basal } \\
\text { ganglia lesion }\end{array}$ \\
\hline Total & 13 & $\begin{array}{l}\mathrm{F}-11 \\
\mathrm{M}-2\end{array}$ & $\begin{array}{l}46-80 \\
(\text { mean 68) }\end{array}$ & $\begin{array}{l}365-1102 \\
\text { (mean 624) }\end{array}$ & $\begin{array}{c}<2 d \\
(1 \text { patient }-4 w)\end{array}$ & $\begin{array}{l}8 \text { - normal } \\
2 \text { - old basal ganglia lesions } \\
2 \text { - hyperdense basal } \\
\quad \text { ganglia lesion }\end{array}$ & $\begin{array}{l}3 \text { MRIs performed - } \\
\text { hyperintense T1 basal } \\
\text { - ganglia lesion }\end{array}$ \\
\hline
\end{tabular}

* Blood glucose levels on admission in $\mathrm{mg} / \mathrm{dl}$.

** $\mathrm{h}$ - hours, $\mathrm{d}-$ days, $\mathrm{w}-$ weeks.

using gamma amino butyric acid - GABA) the activity of the ventrolateral thalamus. Destruction of the subthalamic nucleus ${ }^{11}$ causes a decrease of this inhibitory function and increases thalamic excitation of the motor and premotor cortex, resulting in involuntary movements (Figure 2).

Our patients suffered from hemichorea that was associated with new onset hyperglycemia. The hemichorea resolved shortly after correction of the hyperglycemia, suggesting that the pathophysiology of this movement disorder is related to the metabolic change. Patient 3 was treated with haloperidol, but the quick recovery and lack of recurrence of the hemichorea after cessation of the drug suggests a similar association.

Thirteen cases $^{2-5,12}$ of hyperglycemia-associated hemiballismus/ hemichorea have been reported previously (Table). The syndrome has been fairly uniform. Most patients are female ( $\mathrm{F} / \mathrm{M}$ ratio of $11 / 2$ ), ranging in age from 50 to 80 years. They usually have no history of diabetes mellitus (9/13). They develop choreic or ballistic movements on one side of the body over a period of hours. Serum glucose levels are elevated, in the range of $400-1000 \mathrm{mg} / \mathrm{dl}$. In most patients, a lowering of the serum glucose is sufficient to reverse the movement disorder within 2448 hours (even when the hemichorea lasts for weeks before the treatment $\left.{ }^{6}\right)$. CT scans are normal $(8 / 13)$ or reveal a hyperdense lesion in the basal ganglia, without mass effect. MRI scans of the brain may show hyperintense caudate or putaminal lesions on T1-weighted images without T2 alterations (3/3). The clinical picture in our patients was similar to that described by other authors. This clinical syndrome may be different, however, from the hemichorea reported in patients with known diabetes. ${ }^{7-10} \mathrm{~A}$ recent report by Lee et $\mathrm{al}^{8}$ described eight women with diabetes who developed hemichorea. In those patients and in other case reports ${ }^{9,10}$ the movement disorder was not directly associated with the presence of hyperglycemia and continued, despite normal glucose levels, for days or weeks.

The pathophysiology of hyperglycemia-associated hemichorea/hemiballismus has not been settled. The acute onset of the hemichorea/hemiballismus suggests a vascular lesion. The hyperintense T1-weighted lesions, demonstrated in the three patients studied with MRI, are compatible with a focal hemorrhage or hemorrhagic infarct in the striatum. The rapid disappearance of the movement disorder after correction of the hyperglycemia suggests a direct metabolic influence. In nonketotic hyperglycemia, nerve cells can utilize gammaaminobutyric acid (GABA) as an alternative energy source. ${ }^{4,13}$ Depletion of GABA may cause a decrease in GABAergic activity, thereby decreasing the inhibition of the thalamus by the medial part of the globus pallidus. We believe that the combination of decreased thalamic inhibition and a recent or old 
striatal lesion (which may increase the inhibition of the subthalamic nucleus) may be responsible for the appearance of this unilateral hyperkinetic movement disorder. The female predisposition may be related to postmenopausal alterations of GABA or dopamine receptors. Further study is needed to validate our hypothesis and to explain why female patients are almost exclusively affected.

Undiagnosed diabetes mellitus should always be suspected in patients who develop hemiballistic or hemichoreic movements. If the serum glucose is high, symptomatic therapy with dopamine receptor antagonists may not be required, as the movement disorder usually responds rapidly to correction of hyperglycemia.

\section{REFERENCES}

1. McDowell F, Cedarbaum JM. The extrapyramidal system and disorders of movement. In: Joynt RJ, Griggs RC, Eds. Clinical Neurology. Philadelphia: Lippincot-Raven, 1996; 38.

2. Rector WG, Herlong HF, Moses H. Nonketotic hyperglycemia appearing as choreoathetosis or ballism. Arch Intern Med 1982; 142:154-155.

3. Sanfield JA, Finkel J, Lewis S, Rosen SG. Alternating choreoathetosis associated with uncontrolled diabetes mellitus and basal ganglia calcifications. Diabetes Care 1986;9:100-101.

4. Lin JJ, Chang MK. Hemiballism - hemichorea and nonketotic hyperglycemia. J Neurol Neurosurg Psychiatry 1994;57:748-750.

5. Takamatsu K, Ohta T, Sato S, et al. Two diabetics with hemichorea hemiballism and striatal lesions. No To Shinkei 1995;47:167-172.

6. Lin JJ. Ipsilateral putamen hyperintensity on T1-weighted MRI in nonketotic hyperglycemia with hemiballism-hemichorea: a case report. Parkins Rel Dis 2001;7:319-321.

7. Broderick JP, Hagen T, Brott T, Tomsick T. Hyperglycemia and hemorrhagic transformation of cerebral infarcts. Stroke 1995;26:484-487.

8. Lee BC, Hwang SH, Chang GY. Hemiballismus - hemichorea in older diabetic women: a clinical syndrome with MRI correlation. Neurology 1999;52:646-648.

9. Oerlemans WGH, Moll LCM. Nonketotic hyperglycemia in a young woman, presenting as hemiballism-hemichorea. Acta Neurol Scand 1999;100:411-414.

10. Ziemann U, Koc J, Reimers CD, Finkenstaedt M, Paulus W. Exploration of motor cortex excitability in a diabetic patient with hemiballism-hemichorea. Mov Disord 2000;5:1000-1005.

11. DeLong MR. Primate models of movement disorders of basal ganglia origin. Trends Neurosc 1990;13:281-284.

12. Bedwell SF. Some observations on hemiballismus. Neurology 1960;10:619-622.

13. Guisado R, Arieff AI. Neurologic manifestations of diabetic comas: correlation with biochemical alterations in the brain. Metabolism $1975 ; 24: 665-679$. 